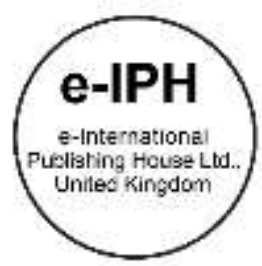

\title{
The Development of Environment \& Occupation Likelihood Scale on Workers Mental Health Status
}

\author{
Mohamad Ghazali Masuri 1,2,3,4, Khairil Anuar Md Isa 1,2,3,4, Jayarajoo Santhanam 5 , \\ Mohd Shukri Mohd Aris ${ }^{1}$, Ismaniza Ismail 6
}

\begin{abstract}
${ }^{1}$ Faculty of Health Sciences, Universiti Teknologi MARA, 42300 Bandar Puncak Alam, Selangor, Malaysia. ${ }^{2}$ Human Factors \& Ergonomics unit, Centre for Occupational Safety, Health and Wellbeing (COSHaW), Universiti Teknologi MARA, 42300 Bandar Puncak

Alam, Selangor, Malaysia. ${ }^{3}$ Associate fellows, Institute for Biodiversity and Sustainable Development (IBSD), Universiti Teknologi MARA, 40450 Shah Alam, Selangor, Malaysia. ${ }^{4}$ Occupational Performance and Behaviour Measurement Group (OPERA) RIG, Faculty of Health Sciences, Universiti Teknologi MARA, Puncak Alam, Malaysia. ${ }^{5}$ Laksamana College of Business, Plaza Abdul Razak, Bandar Seri Begawan, Brunei Darussalam. ${ }^{6}$ School of Chemistry and Environment, Faculty of Applied Sciences, Universiti Teknologi MARA, 40450 Shah Alam, Selangor, Malaysia
\end{abstract}

mghazali@uitm.edu.my, khairil996@uitm.edu.my, jay@laksamanacollege.edu.bn,myshukri@uitm.edu.my, ismaniza@uitm.edu.my

\begin{abstract}
Daily work activities are among the sources of stress to humans. Typically, each individual will spend $1 / 3$ of their day at work. It is no exaggeration to say that $1 / 3$ affects the other 2/3. Appropriate assessments should be conducted to assess what employment factors and the work environment contribute to this. This study explains the development process and the use of the Environmental \& Occupational Probability Scale screening form on mental health status or known as SKiPP. This assessment can be used to measure both of these factors on the mental health status of employees based on the DASS21 score.
\end{abstract}

Keywords: DASS21; Person-Environment-Occupation model; Work-related stress

eISSN: 2398-42870 2021. The Authors. Published for AMER ABRA CE-Bs by e-International Publishing House, Ltd., UK. This is an open access article under the CC BYNCND license (http://creativecommons. org/licenses/by-nc-nd/4.0/). Peer-review under responsibility of AMER (Association of Malaysian Environment-Behaviour Researchers), ABRA (Association of Behavioural Researchers on Asians/Africans/Arabians) and cE-Bs (Centre for Environment-Behaviour Studies), Faculty of Architecture, Planning \& Surveying, Universiti Teknologi MARA, Malaysia.

DOI: https://doi.org/10.21834/ebpj.v6i18.3068

\subsection{Introduction}

Stress in daily life is a common thing that every human being goes through. This stress is sometimes a good thing and can increase selfmotivation and work productivity. However, if this matter is not handled properly, it can cause long-term harm to ourselves, our employers, and those around us. Generally, we spend $1 / 3$ of our day doing work activities at work. This high amount of time greatly contributes to the situation outside of one's working hours. Many questions are raised both in terms of legislation and practice in the workplace about the factors contributing to the stress and health status of these workers. Among the common questions is about the source of stress. Is it the result of the job, or does it come from a source other than the job? Accordingly, a comprehensive study needs to be done to filter the differences between work-related and non-work-related factors. Employers, employees, and several related agencies such as the Department of Occupational Safety \& Health (DOSH) Malaysia, the Social Security Organization (SOCSO), and workers' associations need clear information to help any appropriate intervention to address this problem. Accordingly, a comprehensive study needs to be done to filter the differences between work-related and non-work-related factors. Employers, employees, and several related agencies such as

eISSN: 2398-4287@ 2021. The Authors. Published for AMER ABRA cE-Bs by e-International Publishing House, Ltd., UK. This is an open access article under the CC BYNCND license (http://creativecommons.org/licenses/by-nc-nd/4.0/). Peer-review under responsibility of AMER (Association of Malaysian Environment-Behaviour Researchers), ABRA (Association of Behavioural Researchers on Asians/Africans/Arabians) and cE-Bs (Centre for Environment-Behaviour Studies), Faculty of Architecture, Planning \& Surveying, Universiti Teknologi MARA, Malaysia.

DOI: https://doi.org/10.21834/ebpj.v6i18.3068 
the Department of Occupational Safety \& Health (DOSH) Malaysia, the Social Security Organization (SOCSO), and workers' associations need clear information to help any appropriate intervention to address this problem. Accordingly, a comprehensive assessment should be developed taking into account individual factors (employees), work environment, and individual employment activities. Occupational performance may change over the life span. There were at least three essential components that contributed to these changes, namely, person-environment-occupation. Fundamentally, these changes may also change individual psychological states such as depression, anxiety, and stress. The new norm of current work practice due to COVID19 demands more sensitive and holistic assessment. The scope of observation and study on these three factors is very limited, and it is related to the existing model on human performance in Occupational Therapy practice. Additionally, the development of this assessment only focuses on stress factors arising from employment. Factors other than employees were not involved in this observation. This study proposes holistic mental health evaluation among Malaysian workers. This new assessment will provide a clear picture of the likelihood of Environment and Occupation that influence workers' mental health status. This paper aims to explain the process and analysis of instrument development called; Environment \& Occupation Likelihood Scale on Workers Mental Health Status (LEOs) or in Bahasa Malaysia is known as Skala Kemungkinan Persekitaran \& Pekerjaan (SKiPP) that measure the likelihood of working environment and work activity that contribute to the worker's mental health status at their workplace. Objectives: To develop the SKiPP according to three essential elements adapted from the Person-Environment-Occupation (PEO) model (Law et al., 1996). This assessment will be used as a quick screening tool by employers and employees to identify the working Environment and work activity that has a potential hazard contributing to the mental health status of Malaysian workers.

\subsection{Issues in OSH Compliance (Mental Health) in Malaysia}

According to the Association of Private Counselors Malaysia (2021), in a decade, the prevalence of Malaysians reported with mental health issues has tripled from $10.5 \%$ in 2005 to $29 \%$ in 2015 . Regrettably, until today, resources pertaining to mental health are still low, with psychiatry and mental health budget for 2019 was only $1.13 \%$ of the whole budget in 2019 (Relate Malaysia), and for 2020, there was a cut of RM31mil (Rahim et al. 2020). This is a significant constraint in implementing mental healthcare for those in need. The ratio of psychiatrists and clinical psychologists is also critical, in which only 1 per 100,000 population, and a total of 410 registered psychiatrists in Malaysia (Guan et al., 2018). This severe lacking clearly reflects the impossibility of accommodating the issue at the national level. Despite the high prevalence of mental health issues in Malaysia, mental health literacy remains low, hence leading to the stigma around mental health and the treatment gap. Due to limited knowledge and access to resources and research for data comparison, it is considered a new area to be explored (Samar \& Perveen, 2021; Loo \& Furnham, 2012; Brown, Harris, \& Russell, 2010; Hassan et al., 2018). In many organizations, despite recognizing the value of health and mental well-being among employers, it has not translated into formal organizational budgeting, policies, or processes that make provisions for employees' mental health. Sometimes, mental health is also associated with employees faking it to avoid heavy tasks because they are lazy to work, which worsens the readily complex stigma (Association of Private Counselors Malaysia, 2021).

As a consequence, employers tend to hire only "healthy" workers and discriminate against workers with mental health issues, fearing they might cause problems at work. Another issue that keeps the problem unsolved is the sufferers' inability to identify signs and symptoms of poor mental health. Ibrahim et al. (2019) pointed out higher self-stigma and younger age as negative mental help-seeking attitudes, hence the need to intensify efforts to reduce self-stigma. Information dissemination via awareness campaigns can also help to educate and increase the mental health literacy of the public generally and the workers, specifically in order to ensure they get the required treatment. Most mental health sufferers have difficulties trying to share the problems due to the stigma, and even when they do, they are uncertain of where and how to seek assistance. The geographical distribution of psychiatric services in Malaysia is poor, concentrated only in large cities and towns (Guan et al., 2018). To make things worse, despite the increasing demand during the COVID-19 pandemic, a survey by the World Health Organization (WHO) revealed that mental health services in 130 countries were disrupted (WHO, 2020). Malaysia also faces the same dilemma when more resources are focused on COVID-19 care, and mental health care services are reduced due to Standard Operating Procedures (SOPs). OSH compliance in mental health can also be obstructed by the over-sighted productivity cost, including absenteeism, presenteeism (working while unwell), and staff turnover. Poor mental health is rarely viewed as a valid reason for taking time off work; therefore, workers are more likely to be present when ill. While there is no specific method to calculate the lost productivity costs, investment in mental health care still outweighs the cost for treatment.

\subsection{Method}

The entire development process of this instrument goes through several standard phases. The first phase begins by examining the evidence from existing publications. All this information is filtered and categorized into two main elements, namely, work and Environment. At the same time, interviews were also held with industry players and expert individuals to gain basic views on the issue. This information is again matched to obtain essential and relevant tree questions to be measured at the end. The process of questionnaire development and item selection involved review from a panel of experts. The questionnaire for the work environment and occupational performance was developed through group discussion, interview, and extraction from two resources known as International Labor Law (ILO) (2012) and characteristic of work by Cox et al. (2000). Twenty-three panels of experts from various Occupational Safety and Health (OSH) and other related fields analyzed the item's developer. A total of 277 participants have participated in the pilot stage were 69 males and 208 females. This study manages to extract a total of 10 questions for SKiPP (kindly refer to appendix). The content and face validity result shows a significantly high score. The scores for representativeness and clarity are between 3.60-3.82. With this value, the second stage of development continues. The ten questions developed in the LEOs are divided into two parts, namely employment, and Environment. These values are then translated into the likelihood $(\mathrm{L})$ form and used in the risk matrix. To measure the principal and weighting questions between work and Environment, another instrument was selected as an independent value to measure the person's $(\mathrm{P})$ level of depression, 
anxiety, and stress. The DASS21 was used to measure worker depression, anxiety, and stress level for the personal factor. DASS21, known as Depression, Anxiety \& Stress Scale, is a screening instrument commonly used in Malaysia and most places globally. This DASS21 value is used to reference the Severity value $(S)$ to be translated into the risk matrix calculator. These $L$ and $S$ values are eventually translated into a complete risk matrix as a priority reference. The field testing phase was continued by combining LEOs and DASS21. Screening questions were distributed using social media platforms. There was no physical contact during this data collection process. A total of 865 employees participated in this screening, and the information and demographic breakdown are as shown in table 1. In general, these values of $L$ and $S$ will be multiplied to obtain the actual risk rate. This risk value is entered into the HIRARC matrix table, which is renamed to Likelihood of Environment \& Occupation Mental Health Hazard Hierarchy matrix (MH3). The adaptation of the use of this matrix is similar to the previous study conducted by Masuri (2020).

\subsection{Results \& Discussion}

Table 1 describes the basic demographic data of all respondents in this study. A total of 865 people participated in the questionnaire, of which $61.5 \%$ were female. The age group between 25 to 40 years is the majority group that participated in this study where it accounted for $54.7 \%$ of the total respondents. The Malays dominated the overall respondents at $85.6 \%$, followed by the Chinese at $7 \%$, Indians at $4.1 \%$ and Sabah/Sarawak Bumiputras at 2.8\%. The M40 group is the majority group of participants, which is $48.3 \%$, followed by B40 at $35.2 \%$ and T20 at 16.5\%. As an initial screening measure on the effects of COVID19 on daily life, five 'weighing' questions were developed in this survey, namely; a) impact on mental health, b) impact on finances, c) impact on work productivity, d) impact on social activities, and $\mathrm{e} 0$ impact on quality of life. The overall answers show that in the range of $50 \%$ of each respondent put a low rate. in this regard, and a conclusion has been drawn whereby society, in general, has accepted the effects of this pandemic and is living life as usual.

Table 1. Demographic data

\begin{tabular}{|c|c|c|}
\hline GENDER & FREQUENCY & $(\%)$ \\
\hline Male & 333 & $(38.5)$ \\
\hline Female & 532 & $(61.5)$ \\
\hline \multicolumn{3}{|l|}{ AGE GROUP } \\
\hline $15-24$ & 28 & $(3.2)$ \\
\hline $25-40$ & 472 & $(54.7)$ \\
\hline $41-54$ & 304 & $(35.2)$ \\
\hline Above 55 & 59 & $(6.8)$ \\
\hline \multicolumn{3}{|l|}{ RACES } \\
\hline Malay & 697 & $(85.6)$ \\
\hline Chinese & 57 & $(7.0)$ \\
\hline Indian & 33 & (4.1) \\
\hline Bumiputra Sabah/Sarawak & 23 & $(2.8)$ \\
\hline Others & 4 & $(0.5)$ \\
\hline \multicolumn{3}{|l|}{ INCOME CATEGORIES } \\
\hline B40 & 188 & $(35.2)$ \\
\hline $\mathrm{M} 40$ & 258 & $(48.3)$ \\
\hline T20 & 88 & $(16.5)$ \\
\hline \multicolumn{3}{|l|}{ MARITAL STATUS } \\
\hline Single & 218 & $(25.2)$ \\
\hline Married & 618 & $(71.4)$ \\
\hline Divorce & 24 & $(2.8)$ \\
\hline Others & 5 & $(0.6)$ \\
\hline \multicolumn{3}{|l|}{$\begin{array}{l}\text { COVID Effects on Mental } \\
\text { Health }\end{array}$} \\
\hline Low & 274 & $(51.3)$ \\
\hline High & 260 & $(48.7)$ \\
\hline \multicolumn{3}{|l|}{ COVID Effects on Financial } \\
\hline Low & 271 & $(50.7)$ \\
\hline High & 263 & $(49.3)$ \\
\hline \multicolumn{3}{|l|}{$\begin{array}{l}\text { COVID Effects on } \\
\text { Productivity }\end{array}$} \\
\hline Low & 300 & $(56.2)$ \\
\hline High & 234 & $(43.8)$ \\
\hline \multicolumn{3}{|l|}{$\begin{array}{l}\text { COVID Effects on Social } \\
\text { Activities }\end{array}$} \\
\hline Low & 289 & $(54.1)$ \\
\hline High & 245 & $(45.9)$ \\
\hline \multicolumn{3}{|l|}{$\begin{array}{l}\text { COVID Effects on Quality of } \\
\text { Life }\end{array}$} \\
\hline Low & 326 & $(61.0)$ \\
\hline High & 248 & $(39.0)$ \\
\hline
\end{tabular}


Table 2 shows the distribution of sectors participated by respondents. $80.2 \%$ of the respondents are comprised of the civil servant's group, followed by the manufacturing sector group at $7.5 \%$ and the construction sector at $6 \%$. The respondents for all ten sectors did not show a uniform trend, but each had a relevant representative.

\begin{tabular}{lcc}
\multicolumn{3}{c}{ Table 2. Sectors } \\
\hline SECTORS & FREQUENCY & $\mathbf{( \% )}$ \\
\hline Manufacturing & 64 & $(7.5)$ \\
\hline Mining & 3 & $(.4)$ \\
\hline Construction & 51 & $(6.0)$ \\
\hline Hotels & 4 & $(.5)$ \\
\hline Agriculture & 6 & $(.7)$ \\
\hline Transportation & 12 & $(1.4)$ \\
\hline Public services & 683 & $(80.2)$ \\
\hline Utilities & 9 & $(1.1)$ \\
\hline Financial & 14 & $(1.6)$ \\
\hline Trade & 6 & $(0.7)$ \\
\hline
\end{tabular}

Table 3 shows the distribution of DASS21 scores. The severity of depression, anxiety and stress varies. however, normal and mild values can be inferred to be in the majority category. The normal score for stress is the highest at $62.4 \%$ followed by depression (normal) $55 \%$ and anxiety (normal) $46.9 \%$. The highest very severe scores started with anxiety $16.1 \%$, followed by depression $5.7 \%$ and stress $2.3 \%$. Those in this category and the severe category are advised to be referred to a psychiatrist and clinical psychologist. However, this study did not provide any channel for further action as all personal information was not collected in order to maintain the sensitivity of the respondents.

\begin{tabular}{lcc}
\multicolumn{3}{c}{ Table 3. DASS21 score } \\
\hline Depression & FREQUENCY & $(\%)$ \\
\hline Normal & 476 & $(55.0)$ \\
\hline Mild & 77 & $(8.9)$ \\
\hline Moderate & 177 & $(20.5)$ \\
\hline Severe & 86 & $(9.9)$ \\
\hline Very Severe & 49 & $(5.7)$ \\
\hline Anxiety & FREQUENCY & $(\%)$ \\
\hline Normal & 406 & $(46.9)$ \\
\hline Mild & 74 & $(8.6)$ \\
\hline Moderate & 165 & $(19.1)$ \\
\hline Severe & 81 & $(9.4)$ \\
\hline Very Severe & 139 & $(16.1)$ \\
\hline Stress & FREQUENCY & $(\%)$ \\
\hline Normal & 540 & $(62.4)$ \\
\hline Mild & 105 & $(12.1)$ \\
\hline Moderate & 140 & $(16.2)$ \\
\hline Severe & 60 & $(6.9)$ \\
\hline Very Severe & 20 & $(2.3)$ \\
\hline
\end{tabular}

By conducting this screening, the underlying values of LEOs can be analyzed where environmental and occupational factors can be isolated and assessed objectively. The cut-off value of this assessment is explained in figure 1. A copy of the Malay version of the question can be referred to in the appendix at the end of this article. Figure 1 shows the findings values from the LEOs filter. These cut-off values were analyzed based on the percentile principle and divided into five likelihood levels $(L)$. This $L$ value is entered in the vertical part while the severity (S) DASS21 is entered in the horizontal part. By using the formula LXS, the risk value can be calculated and translated into a color form. The application of the use of this matrix is young where, the total score of questions 1 - 5 LEOs is used to assess the likelihood of employment factors followed by questions 6 - 10 for environmental factors. It is hoped that this objective assessment will be able to assist employers, employees and DOSH in the future in monitoring psychosocial and mental health issues in the workplace.

Fig. 1: Occupation \& Environment cut off value for the determination of likelihood - MH3

\begin{tabular}{|c|c|c|c|c|c|c|c|}
\hline \multirow{2}{*}{$\begin{array}{l}\text { Q1-Q5: Cut-off value } \\
\text { for Occupation }\end{array}$} & \multirow{2}{*}{\multicolumn{2}{|c|}{ Likelihood (L) }} & \multicolumn{5}{|c|}{ DASS21 } \\
\hline & & & \multirow{2}{*}{ Normal } & \multirow[t]{2}{*}{ Mild } & \multirow[t]{2}{*}{ Moderate } & \multirow[t]{2}{*}{ Severe } & \multirow[t]{2}{*}{ Very Severe } \\
\hline $5-8$ & No & 1 & & & & & \\
\hline $8.1-12$ & Low & 2 & & & & & \\
\hline $12.1-16$ & Medium & 3 & & & & & \\
\hline $16.1-19.5$ & High & 4 & & & & & \\
\hline$>19.6$ & Very High & 5 & & & & & \\
\hline \multirow{2}{*}{$\begin{array}{l}\text { Q6-Q10: Cut-off value } \\
\text { for Environment }\end{array}$} & \multirow{2}{*}{\multicolumn{2}{|c|}{ Likelihood (L) }} & \multicolumn{5}{|c|}{ DASS21 } \\
\hline & & & Normal & Mild & Moderate & Severe & Very Severe \\
\hline $5-6$ & No & 1 & & & & & \\
\hline
\end{tabular}




\begin{tabular}{|c|c|c|c|c|c|c|c|}
\hline $6.1-10$ & Low & 2 & & & & & \\
\hline $10.1-15$ & Medium & 3 & & & & & \\
\hline $15.1-20$ & High & 4 & & & & & \\
\hline$>20.1$ & Very High & 5 & & & & & \\
\hline
\end{tabular}

\subsection{Limitations}

Measurement of mental health status is very challenging. The complexity of human components such as emotion and cognitive status may change over time due to external and non-occupation factors, contributing to changes in the assessment score. However, the current result is valid to be referred to on a 'time of assessment' basis. This study is also aware that the value of the casting used requires detailed study and further field testing. Tests in real situations involving employers and employees from specific sectors will be able to provide more accurate and precise answers. Hopefully, the industry will provide support and input from time to time to make this agenda a success. In addition, the ability and influence of the authorities in making this assessment and action plan as one of the policies in line with ISO45003: 2021 will be able to jump and make the psychosocial actions of employment in Malaysia in line with international practice. International cooperation and input received from time to time will also be an added value of the feasibility of this program. Please be reminded, all proposals for the use of this process are also subject to the approval and support of the ministry, through DOSH. This pilot study is a good action in preparing employers and employees in dealing with psychosocial issues of employment in the workplace.

\section{Acknowledgements}

The highest appreciation goes to the Ministry of Higher Education Malaysia (MoHE), Royal Malaysia Police, Research Management Centre (RMC), Universiti Teknologi MARA (UiTM), CoRe Management Science, OPERA RIG, to all panel experts as well as respondents who had participated in this study for their kind cooperation and to all staff of the Faculty of Health Sciences UiTM Puncak Alam for continuous support in staff research and development. Thank you to our local and international collaborators, Ministry of Health Malaysia, PERKESO, PETRONAS, MIROS Malaysia, The Robert Gordon University, UK, Tokyo University of Technology, Japan, Honam University, South Korea, Kolej Laksamana, Brunei, and Universiti Indonesia, Indonesia. This study was funded by DOSH Malaysia- JKKP/07/2021/MD.

\section{Paper Contribution to Related Field of Study}

The findings of the study from this first edition will certainly provide stimulation and understanding of fundamental issues to occupational mental health contributors. The proposed matrix table is also still open to any constructive comments and criticism. It is the desire of researchers and the DOSH, Malaysia, to see the positive effects of the results of this study. Employers, employees, and the community need to provide useful input in ensuring that this is better for the future. There is always room for improvement for the next edition, and the start is here for the entire Malaysian industry.

\section{References}

Association of Private Counselors Malaysia (2021), https://my-confidential.org/

HealthMetrics (2021) HR Guide: Employee Mental Wellness in the Workplace.

Kohn R, Saxena S, Levav I, Saraceno B. The treatment gap in mental health care. Bull World Health Organ (2004) 82(11):858-66. doi: 10.1590/S004296862004001100011.

Law M, Cooper B, Strong S, Stewart D, Rigby P, Letts L. The Person-Environment-Occupation Model: A Transactive Approach to Occupational Performance. Canadian Journal of Occupational Therapy. 1996;63(1):9-23. doi:10.1177/000841749606300103

Masuri, M. G., Dahlan, A., Md Isa, K. A., \& Hashim, R. (2020). The Application of HIRARC on Attitude towards Safe Driving Scale (ASDS) according to PreSiM Model. Environment-Behaviour Proceedings Journal, 5(14), 281-286. https://doi.org/10.21834/ebpj.v5i14.2182

Samar, N., \& Perveen, A. (2021). Relationship Between Mental Health Literacy and Help Seeking Behavior Among Undergraduate Students. International Journal of Academic Research in Business and Social Sciences, 11(6), 216-230.

Hassan, M. F., Hassan, N. M., Kassim, E. S., \& Hamzah, M. I. (2018). Issues and Challenges of Mental Health in Malaysia. International Journal of Academic Research in Business and Social Sciences, 8(12), 1685-1696.

Loo, P.-W., \& Furnham, A. (2012). Public knowledge and beliefs about depression among urban and rural Chinese in Malaysia. Asian Journal of Psychiatry, 5(3), 236-245

Brown, V. A., Harris, J. A., \& Russell, J. Y. (2010). Tackling wicked problems through the transdisciplinary imagination. Earthscan. Rahim, R, Tan, T and Carvalho, M (2020) Minister denies cut in mental health allocation under Budget 2021, The Star, Accessed on 3rd Nov 2021 at https://www.thestar.com.my/news/nation/2020/11/18/ministerdenies-cut-in-mental-health-allocation-under-budget-2021

Guan, NC, Lee, TC, Francis, B, Yen, TS. . Psychiatrists in Malaysia: the ratio and distribution. Malays J Psychiatry 2018; 27(1): 4-12. 
Masuri, M.G., et.al., AQoL2021, 5th ABRA International Conference on Quality of Life, Holiday Villa Langkawi, Malaysia, 15-16 Dec 2021, E-BPJ, 6(18), Dec 2021 (pp.163-173)

World Health Organization (WHO), (2020) COVID-19 disrupting mental health services in most countries, WHO survey, Accessed on $5^{\text {th }}$ Oct 2020 at https://www.who.int/news/item/05-10-2020-covid-19-disrupting-mental-health-services-in-most-countries-who-survey 


\section{Appendix}

\section{Skala Kemungkinan Pekerjaan \& Persekitaran terhadap status kesihatan mental pekerja (SKiPP)}

Skala Kemungkinan Persekitaran \& Pekerjaan terhadap status kesihatan mental pekerja (SKiPP) merupakan satu instrument saringan yang berpandukan International Labour Organization (ILO) dan sejajar dengan perkembangan ISO 45003: 2021 Occupational Health and Safety Management - Psychological Health and Safety at Work Guidelines for Managing Psychosocial Risks. SKiPP digunakan bagi menilai kemungkinan persekitaran tempat kerja dan aktiviti pekerjaan seseorang pekerja itu menyumbang kepada status kesihatan mental mereka. Terdapat 10 soalan yang perlu dinilai dengan menggunakan skala $1-5$ berdasarkan kepada tiga (3) tempoh masa yang berbeza. Pekerja boleh mengisi penilaian ini bagi mengetahui tahap kemungkinan sesuatu faktor itu menyumbang kepada status kesihatan mental mereka. Saringan awal ini akan dapat membantu pekerja dan majikan mengambil tindakan sewajarnya. Sila baca setiap pernyataan di bawah dan pilih pada skala 1,2, 3, 4 atau 5 bagi menggambarkan kemungkinan persekitaran \& pekerjaan yang menyumbang kepada status kesihatan mental anda.

Skala kemungkinan:
1. Tiada.
2. Rendah.
3. Sederhana.
4. Tinggi.
5. Sangat tinggi.

Maklumat peribadi pekerja**:

\begin{tabular}{lll}
\hline Nama & $:$ Bangsa \\
\hline Jantina & $:$ Status \\
\hline Umur & $:$ & Jabatan \\
\hline
\end{tabular}

**boleh ditambah mengikut keperluan majikan.

Baca setiap pernyataan di bawah dan bulatkan pilihan anda berdasarkan skala kemungkinan berikut:
Tiada
Rendah
Sederhana
Tinggi
Sangat tinggi

Kemungkinan perkara-perkara ini menyumbang kepada status kesihatan mental saya...

1 Keselesaan kerja: Membosankan, kurang rangsangan, tidak bermakna, kurang kepelbagaian.

\begin{tabular}{|c|c|c|c|c|}
\hline Sekarang & 1 & 2 & 3 & 4 \\
\hline 6 bulan lalu 1 & 2 & 3 & 4 & 5 \\
\hline 12 bulan lalu & 1 & 2 & 3 & 4 \\
\hline
\end{tabular}

2 Beban kerja: Terlebih beban kerja, bekerja bawah tekanan masa.

\begin{tabular}{|c|c|c|c|c|}
\hline Sekarang & 1 & 2 & 3 & 4 \\
\hline 6 bulan lalu 1 & 2 & 3 & 4 & 5 \\
\hline 12 bulan lalu & 1 & 2 & 3 & 4 \\
\hline
\end{tabular}

3 Jam kerja: Panjang, tiada fleksibiliti, tidak terjangka, susun atur masa yang teruk, tiada masa bersosial.

$\begin{array}{llllll}\text { Sekarang } & 1 & 2 & 3 & 4 & 5 \\ 6 \text { bulan lalu 1 } & 2 & 3 & 4 & 5 & \\ 12 \text { bulan lalu } & 1 & 2 & 3 & 4 & 5\end{array}$

$4 \quad$ Penglibatan dan kawalan kerja: Tidak terlibat dalam membuat keputusan, tidak boleh mengawal proses, kelajuan, masa dan persekitaran.

$\begin{array}{llllll}\text { Sekarang } & 1 & 2 & 3 & 4 & 5 \\ 6 \text { bulan lalu 1 } & 2 & 3 & 4 & 5 & \\ 12 \text { bulan lalu } & 1 & 2 & 3 & 4 & 5\end{array}$

$5 \quad$ Alatan dan ruang kerja: Tidak lengkap, tidak diselenggara dengan sempurna, risiko ergonomik, terdedah kepada bahaya.

$\begin{array}{llllll}\text { Sekarang } & 1 & 2 & 3 & 4 & 5 \\ 6 \text { bulan lalu 1 } & 2 & 3 & 4 & 5 & \\ 12 \text { bulan lalu } & 1 & 2 & 3 & 4 & 5\end{array}$

$6 \quad$ Perkembangan kerjaya: Kerja tiada jaminan, tiada naik pangkat/gaji, penilaian prestasi tidak adil, kerja dilakukan bawah kemahiran sebenar, tiada latihan. 


$\begin{array}{llllll}6 \text { bulan lalu } 1 & 2 & 3 & 4 & 5 & \\ 12 \text { bulan lalu } & 1 & 2 & 3 & 4 & 5\end{array}$

7 Peranan dalam organisasi: Peranan tidak jelas, konflik peranan dengan yang lain.

$\begin{array}{llllll}\text { Sekarang } & 1 & 2 & 3 & 4 & 5 \\ 6 \text { bulan lalu 1 } & 2 & 3 & 4 & 5 & \\ 12 \text { bulan lalu } & 1 & 2 & 3 & 4 & 5\end{array}$

8 Hubungan sesama rakan: Tidak mendapat sokongan, hubungan tidak baik antara rakan sekerja, dibuli, diganggu, kerja terasing dengan orang lain, ketua mementingkan diri, layanan kasar.

$\begin{array}{llllll}\text { Sekarang } & 1 & 2 & 3 & 4 & 5 \\ 6 \text { bulan lalu 1 } & 2 & 3 & 4 & 5 & \\ 12 \text { bulan lalu } & 1 & 2 & 3 & 4 & 5\end{array}$

9 Budaya organisasi: Komunikasi tidak berkesan, kepimpinan/tingkahlaku organisasi yang tidak baik, pengurusan tidak jelas, objektif tidak jelas, strategi tidak jelas.

$\begin{array}{llllll}\text { Sekarang } & 1 & 2 & 3 & 4 & 5 \\ 6 \text { bulan lalu 1 } & 2 & 3 & 4 & 5 & \\ 12 \text { bulan lalu } & 1 & 2 & 3 & 4 & 5\end{array}$

10 Keseimbangan kerja dan kehidupan harian: Konflik kerja dan urusan rumah, kurang sokongan masalah domestik di tempat kerja, kurang sokongan masalah kerja di rumah, kurang peraturan, sokongan dan polisi berkaitan keseimbangan kerja dan kehidupan harian.

$\begin{array}{llllll}\text { Sekarang } & 1 & 2 & 3 & 4 & 5 \\ 6 \text { bulan lalu 1 } & 2 & 3 & 4 & 5 & \\ 12 \text { bulan lalu } & 1 & 2 & 3 & 4 & 5\end{array}$

\begin{tabular}{|c|c|c|c|c|c|c|c|}
\hline \multirow{2}{*}{$\begin{array}{l}\text { S1-S5: Nilai cut-off kategori } \\
\text { (Pekerjaan) }\end{array}$} & \multirow{2}{*}{\multicolumn{2}{|c|}{ Likelihood (L) }} & \multicolumn{5}{|c|}{ DASS21 } \\
\hline & & & \multirow{2}{*}{ Normal } & \multirow[t]{2}{*}{ Ringan } & \multirow{2}{*}{ Sederhana } & \multirow[t]{2}{*}{ Teruk } & \multirow[t]{2}{*}{ Sangat teruk } \\
\hline $5-8$ & TIADA & 1 & & & & & \\
\hline $8.1-12$ & RENDAH & 2 & & & & & \\
\hline $12.1-16$ & SEDERHANA & 3 & & & & & \\
\hline $16.1-19.5$ & TINGGI & 4 & & & & & \\
\hline$>19.6$ & SANGAT TINGGI & 5 & & & & & \\
\hline \multirow{2}{*}{$\begin{array}{c}\text { S6-S10: Nilai cut-off } \\
\text { kategori (Persekitaran) }\end{array}$} & \multirow{2}{*}{\multicolumn{2}{|c|}{ Likelihood (L) }} & \multicolumn{5}{|c|}{ DASS21 } \\
\hline & & & Normal & Ringan & Sederhana & Teruk & Sangat teruk \\
\hline $5-6$ & TIADA & 1 & & & & & \\
\hline $6.1-10$ & RENDAH & 2 & & & & & \\
\hline $10.1-15$ & SEDERHANA & 3 & & & & & \\
\hline $15.1-20$ & TINGGI & 4 & & & & & \\
\hline$>20.1$ & SANGAT TINGGI & 5 & & & & & \\
\hline
\end{tabular}

